\title{
Energy and nitrogen balance of dairy cattle as affected by provision of different essential amino acid profiles at the same metabolizable protein supply
}

\author{
K. Nichols, ${ }^{1,2 *}$ A. Bannink, ${ }^{2}$ and J. Dijkstra ${ }^{1}$ \\ ${ }_{1}^{1}$ Animal Nutrition Group, Wageningen University and Research, PO Box 338, $6700 \mathrm{AH}$ Wageningen, the Netherlands \\ ${ }^{2}$ Wageningen Livestock Research, Wageningen University and Research, PO Box 338, 6700 AH Wageningen, the Netherlands
}

\section{ABSTRACT}

Amino acid composition of metabolizable protein (MP) is important in dairy cattle diets, but effects of AA imbalances on energy and $\mathrm{N}$ utilization are unclear. This study determined the effect of different AA profiles within a constant supplemental MP level on whole-body energy and $\mathrm{N}$ partitioning in dairy cattle. Five rumenfistulated Holstein-Friesian dairy cows $(2.8 \pm 0.4$ lactations; $81 \pm 11 \mathrm{~d}$ in milk; mean \pm standard deviation) were randomly assigned to a $5 \times 5$ Latin square design in which each experimental period consisted of $5 \mathrm{~d}$ of continuous abomasal infusion followed by $2 \mathrm{~d}$ of rest. A total mixed ration consisting of $58 \%$ corn silage, $16 \%$ alfalfa hay, and $26 \%$ concentrate (dry matter basis) was formulated to meet 100 and $83 \%$ of net energy and MP requirements, respectively, and was fed at $90 \%$ of ad libitum intake by individual cow. Abomasal infusion treatments were saline (SAL) or $562 \mathrm{~g} / \mathrm{d}$ of essential AA delivered in 4 profiles where individual AA content corresponded to their relative content in casein. The profiles were (1) a complete essential amino acid mixture (EAAC), (2) Ile, Leu, and Val (ILV), (3) His, Ile, Leu, Met, Phe, Trp, Val (GR1+ILV), and (4) Arg, His, Lys, Met, Phe, Thr, Trp (GR1+ALT). The experiment was conducted in climate respiration chambers to determine energy and $\mathrm{N}$ balance in conjunction with milk production and composition, digestibility, and plasma constituents. Compared with SAL, infusion of EAAC increased milk, protein, and lactose yield, increased energy retained as body protein, and did not affect milk $\mathrm{N}$ efficiency. Total $\mathrm{N}$ intake and urine $\mathrm{N}$ output was higher with all AA infusions relative to SAL. Compared with EAAC, infusions of GR1+ILV and GR1+ALT produced the same milk yield and the same yield and content of milk fat, protein, and lactose, and had similar energy and $\mathrm{N}$ retention. Milk $\mathrm{N}$ efficiency was not

Received January 30, 2019.

Accepted June 7, 2019.

*Corresponding author: kelly.nichols@wur.nl different between EAAC and GR1+ILV, but was lower with GR1+ALT compared with EAAC, and tended to be lower with GR1+ALT compared with GR1+ILV. Infusion of ILV tended to decrease dry matter intake compared with the other AA infusions. Milk production and composition was not different between ILV and SAL. Compared with EAAC, infusion of ILV decreased or tended to decrease milk, protein, and lactose yields and milk protein content, and increased milk fat and lactose content. Milk N efficiency decreased with ILV compared with SAL, EAAC, and GR1+ILV. Milk urea concentration was not affected by essential amino acid (EAA) infusions. Plasma urea concentration did not differ between EAAC and SAL, tended to increase with ILV and GR1+ILV over SAL, and increased with GR1+ALT compared with EAAC and SAL. In conclusion, removing Arg, Lys, and Thr or removing Ile, Leu, and Val from a complete EAA profile when the total amount of EAA infused remained constant did not impair milk production, but milk $\mathrm{N}$ efficiency decreased when Ile, Leu, and Val were absent. Infusion of only Ile, Leu, and Val decreased milk protein yield and content and reduced milk $\mathrm{N}$ efficiency compared with a complete EAA profile.

Key words: energy balance, nitrogen balance, milk nitrogen efficiency, amino acid imbalance, metabolizable protein

\section{INTRODUCTION}

Dietary protein for lactating dairy cattle must allow a quantitatively and qualitatively optimal absorptive AA supply to support maintenance, reproduction, and milk protein synthesis. Simply increasing total absorptive AA supply does not guarantee positive responses in milk protein synthesis, because transfer efficiency of absorbed AA-N into milk protein generally decreases (Doepel et al., 2004; Huhtanen and Hristov, 2010) and AA catabolism and $\mathrm{N}$ excretion increases (Bach et al., 2000; Castillo et al., 2001; Raggio et al., 2004) as AA supply increases. However, when MP supply delivers a 
desirable EAA profile for milk protein synthesis, milk $\mathrm{N}$ efficiency can be improved (Arriola Apelo et al., 2014). Within EAA, groups can be distinguished with respect to their use by splanchnic and peripheral tissues (Lapierre et al., 2005). Differences in metabolism of EAA as individuals and as functional groups may affect $\mathrm{N}$ partitioning at the whole-body level. Group 1 AA (His, Met, Phe+Tyr, Trp) are transferred from the mammary arterial blood supply into milk in a $1: 1$ ratio (Mepham, 1982; Lapierre et al., 2012). Group 2 AA (Arg, Ile, Leu, Lys, Thr, and Val) are extracted by the mammary gland in excess of their output in milk. Excess $\mathrm{N}$ and carbon from group $2 \mathrm{AA}$ relative to their output in milk is used for de novo NEAA synthesis and as tricarboxylic acid cycle intermediates in mammary cells (Mepham, 1982; Lapierre et al., 2012). With respect to extra-mammary metabolism, group $1 \mathrm{AA}$ are subject to hepatic catabolism (particularly His, Met, and Phe; Raggio et al., 2004; Lapierre et al., 2005), whereas the branched-chain amino acids (BCAA; Ile, Leu, and Val) and Lys are preferentially catabolized in the periphery (Lapierre et al., 2005; Brosnan and Brosnan, 2006). Arginine can be considered a semiessential AA, as it can be synthesized de novo (Doepel et al., 2004), but likely at insufficient levels relative to requirements of high-producing dairy cattle (NRC, 2001).

Milk production responses to postruminally infused AA mixtures are often not attributable to supplementation or deletion of a single AA (Schwab et al., 1976; Kim et al., 2000; Doelman et al., 2015a). Furthermore, supplementing single AA may inhibit efficient milk protein production by increasing competition across AA countertransport systems in mammary cells (Maas et al., 1998), and by inducing metabolic imbalances resulting in energy-costly functions for catabolism and excretion of excess AA (Weekes et al., 2006; Calsamiglia et al., 2010; Reed et al., 2017). Therefore, under practical feeding conditions, focus should be placed on formulating rations with a wider profile of EAA in MP, rather than on supplementation of single AA. Several studies have investigated milk production and $\mathrm{N}$ metabolism in response to MP supplements and dietary ingredients providing wider EAA profiles (Bach et al., 2000; Haque et al., 2012; Maxin et al., 2013), but quantification of the effect of EAA profile of MP on whole-body energy and $\mathrm{N}$ partitioning requires further refinement.

Previous studies have evaluated the effects of EAA deficiencies in duodenal supply, where single AA or groups of AA were subtracted from postruminal infusions of complete AA profiles (Weekes et al., 2006; Doelman et al., 2015a,b). Our objective was to investigate whole-body energy and $\mathrm{N}$ metabolism when lactating dairy cattle were supplemented with a constant level of supplemental MP that varied in EAA profile. We expected that when BCAA or non-branched-chain group 2 AA (Arg, Lys, and Thr) are absent from a complete EAA profile but their supply is compensated by other EAA, differences in $\mathrm{N}$ balance might be observed. We expected these differences due to the affinity of BCAA and Lys for metabolism in extra-hepatic tissues, and the ability of Arg to be endogenously produced. Specifically, we hypothesized that an infusion lacking Arg, Lys, and Thr would result in similar milk protein yield and whole-body $\mathrm{N}$ balance compared with a complete EAA profile, and that an infusion lacking BCAA might reduce milk protein yield. We expected that, at the same supplemental MP level, an infusion of BCAA alone would have a negative effect on energy balance, milk protein production, and milk $\mathrm{N}$ efficiency compared with a complete EAA profile, due to the absence of group $1 \mathrm{AA}$ and a relatively greater imbalance in EAA supply.

\section{MATERIALS AND METHODS}

\section{Experimental Design and Respiration Chamber Housing}

The following experimental procedures were conducted under the Dutch Law on Animal Experiments in accordance with European Union Directive 2010/63. Five rumen-fistulated, Holstein-Friesian dairy cows were randomly assigned to a $5 \times 5$ Latin square design where each experimental period consisted of $5 \mathrm{~d}$ of continuous abomasal infusion followed by $2 \mathrm{~d}$ of rest (Figure 1). Cows were in second $(\mathrm{n}=1)$ or third $(\mathrm{n}=$ 4) lactation with an average milk production of $33.1 \pm$ $2.28 \mathrm{~kg} / \mathrm{d}$ at $81 \pm 11 \mathrm{DIM}$ and $631 \pm 71.1 \mathrm{~kg}$ of BW. Cows were adapted to the experimental conditions for $19 \mathrm{~d}$ before the first experimental period. For the first $14 \mathrm{~d}$ of adaptation, cows were housed individually in tiestalls for acclimatization to the diet and the restriction in movement. From d 15 of the adaptation period, cows were housed individually in identical climate respiration chambers (CRC) for $5 \mathrm{~d}$ of adaptation before the first experimental period began. Cows were housed in CRC for the entire experiment to facilitate determination of gaseous exchange, energy and $\mathrm{N}$ balance, and apparent total-tract nutrient digestibility (ATTD). Detailed descriptions of the CRC design and gas measurements are given by Heetkamp et al. (2015) and van Gastelen et al. (2015). Briefly, each CRC compartment measured $11.8 \mathrm{~m}^{2}$ and had a volume of $34.5 \mathrm{~m}^{3}$. The ventilation rate was $43 \mathrm{~m}^{3} / \mathrm{h}$, relative humidity was maintained at $65 \%$, and temperature was maintained at $16^{\circ} \mathrm{C}$ inside each compartment. The CRC were designed with thin walls equipped with windows to allow audio and visual 


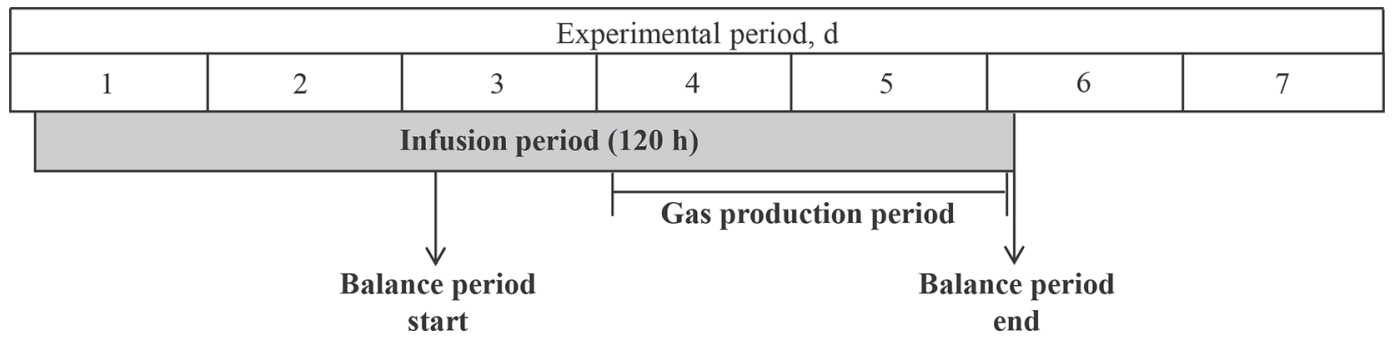

Figure 1. Design of a single 7-d experimental period. The 120-h infusion period began at $0900 \mathrm{~h}$ on $\mathrm{d} 1$ and ended at $0900 \mathrm{~h}$ on $\mathrm{d} 6 \mathrm{of}$ each experimental period. The infusion period was followed by a 48 -h wash-out period. Balance period $=71$-h period of total manure collection with milk and feces samples from $1000 \mathrm{~h}$ on d 3 until $0900 \mathrm{~h}$ on d 6 . Gas production period $=48$-h period of gas production and consumption measured from $0800 \mathrm{~h}$ on $\mathrm{d} 4 \mathrm{until} 0800 \mathrm{~h}$ on $\mathrm{d} 6$.

contact between cows and minimize the effects of social isolation on behavior and performance. Cows were exposed to $17.5 \mathrm{~h}$ of light per d (0530 to $2300 \mathrm{~h}$ ).

Gas concentrations and ventilation rates were corrected for pressure, temperature, and relative humidity to arrive at standard temperature and pressure dew point volumes of inlet and exhaust air. Consumption of $\mathrm{O}_{2}$ and production of $\mathrm{CO}_{2}$ and $\mathrm{CH}_{4}$ inside each chamber was calculated from the difference between inlet and exhaust gas volumes. Gas analysis in this experiment was performed as described by van Gastelen et al. (2015), where 4 CRC compartments shared a single gas analyzer, but with the addition of a second gas analyzer measuring gas from the 1 additional CRC compartment in 6-min intervals. Calibration gases were sampled once daily instead of the inlet air. The analyzed and actual values of these calibration gases were used to correct the analyzed gas concentrations from the inlet and exhaust air of the 5 chambers. Before the experiment started, $\mathrm{CO}_{2}$ recovery was checked by releasing known amounts of $\mathrm{CO}_{2}$ into each chamber and comparing the known values with data from the gas analysis system to calculate the recovery. The recovered amounts of $\mathrm{CO}_{2}$ were between 99 and $100 \%(99.3 \pm 0.41 \%)$. Gas measurements during time points when staff entered the CRC compartments (maximum 30 min for milking, feeding, checking abomasal infusion lines) were discarded from the data analysis. Consumption of $\mathrm{O}_{2}$ and production of $\mathrm{CO}_{2}$ and $\mathrm{CH}_{4}$ was assumed to be linear between the last data point before opening and the first data point after closing the CRC.

\section{Diet, Feeding, and Treatment Infusions}

Cows were fed a TMR consisting of $58 \%$ corn silage, $16 \%$ alfalfa hay, and $26 \%$ concentrate on a DM basis (Table 1), formulated to meet 100 and $83 \%$ of $\mathrm{NE}_{\mathrm{L}}$ and MP requirements (CVB, 2008), respectively, for cows consuming $21 \mathrm{~kg}$ of DM/d and producing $33 \mathrm{~kg} / \mathrm{d}$ of milk containing $4.1 \%$ fat and $3.4 \%$ protein. The supply of individual digestible EAA from the diet is presented in Table 2. Cows had individual and free access to drinking water throughout the entire experiment. Cows were fed ad libitum for the first $10 \mathrm{~d}$ of the 19-d adaptation period. Intake during the final $5 \mathrm{~d}$ of the $10-\mathrm{d}$ ad libitum intake period was used to calculate a $10 \%$ daily intake restriction for individual cows. Cows were fed this fixed amount from d 11 of adaptation for the remainder of the adaptation and experimental periods described above. Fresh feed was allocated twice daily at 0530 and $1530 \mathrm{~h}$ by manually mixing the roughage and concentrate portions into a TMR for individual cows. The roughage portion (corn silage + alfalfa hay) of the diet was mixed twice weekly and stored at $4^{\circ} \mathrm{C}$ for no longer than $4 \mathrm{~d}$ before feeding. The concentrate contained $0.25 \%$ titanium dioxide as an inert marker for estimation of ATTD. Feed refusals at each feeding time point were collected and weighed to determine daily feed intake. For a 58 -h period over d 3 to 5 of each experimental period ( $0530 \mathrm{~h}$ on d 3 until $1530 \mathrm{~h}$ on d 5 ), cows were fed using an automated feeding system that dispensed equal portions of feed every $2 \mathrm{~h}$ to promote metabolic steady-state conditions in preparation for the blood sampling protocol described below.

Infusion lines were placed in the abomasum via the rumen cannula $2 \mathrm{~d}$ before the first experimental period and were checked daily for patency and position. The abomasal infusion device has been described by Nichols et al. (2019). Infusion treatments were $0.9 \%$ saline (SAL) or $562 \mathrm{~g} / \mathrm{d}$ of AA delivered in 4 different profiles (Table 2) consisting of (1) a complete EAA mixture (EAAC), (2) Ile, Leu, and Val (ILV), (3) His, Ile, Leu, Met, Phe, Trp, Val (GR1+ILV), and (4) Arg, His, Lys, Met, Phe, Thr, Trp (GR1+ALT). Within each AA infusion, EAA were infused in amounts relative to their content in casein, according to Metcalf et al. (1996). Including intake from the restricted feeding level of the basal diet plus the infusions, target requirements for $\mathrm{NE}_{\mathrm{L}}$ and $\mathrm{MP}$ were formulated to be met to 90 and $75 \%$, respectively, for SAL, and 95 and $104 \%$, 
Table 1. Ingredient composition of TMR and analyzed and calculated chemical composition of ingredients (corn silage, alfalfa hay, and concentrate) and complete TMR ( $\mathrm{g} / \mathrm{kg}$ of DM, unless otherwise noted)

\begin{tabular}{lcccc}
\hline & \multicolumn{3}{c}{ Ingredient } & \\
\cline { 2 - 3 } Item & Corn silage & Alfalfa hay & Concentrate $^{2}$ & \multirow{2}{*}{ TMR $^{1}$} \\
\hline Inclusion & 580 & 157 & 263 & - \\
Chemical composition & & & & \\
DM, g/kg & 334 & 896 & 898 & 456 \\
GE, MJ/kg of DM & 18.8 & 18.2 & 17.0 & 18.2 \\
Crude ash & 37 & 92 & 115 & 66 \\
CP & 77 & 120 & 252 & 130 \\
Crude fat & 30 & 13 & 35 & 28 \\
NDF & 372 & 549 & 167 & 346 \\
ADF & 210 & 435 & 84 & 212 \\
ADL & 10 & 86 & 15 & 23 \\
Starch & 347 & NA & 287 & 277 \\
Sugar & NA & 46 & 79 & 28 \\
DVE & 55 & 54 & 135 & 76 \\
OEB $^{6}$ & -45 & 2 & 106 & 2 \\
NE $_{\mathrm{L}}{ }^{7}{ }^{4}$ MJ/kg of DM & 6.99 & 4.55 & 8.07 & 6.89 \\
\hline
\end{tabular}

${ }^{1}$ Values for TMR were calculated based on ration composition and analyzed and calculated values obtained for roughages and concentrate.

${ }^{2}$ Contained (g/kg of DM): ground corn $8 \% \mathrm{CP}, 406$; solvent-extracted rapeseed meal $34 \% \mathrm{CP}, 182$; beet pulp $19 \%$ sugar, 164; soybean meal $49 \% \mathrm{CP}, 127$; urea, 23; limestone $37 \% \mathrm{Ca}$, 19; sodium bicarbonate, 18; magnesium sulfate, 16; magnesium oxide, 13; Hidropalm, 12 (Norel Animal Nutrition, Madrid, Spain); monocalcium phosphate, 9; trace mineral and vitamin premix, $7 ; \mathrm{NaCl}, 6 ; \mathrm{TiO}_{2}$ was included at $0.25 \%$ of concentrate DM.

${ }^{3} \mathrm{GE}=$ gross energy.

${ }^{4} \mathrm{NA}=$ not analyzed

${ }^{5}$ Intestinal digestible protein (CVB, 2008).

${ }^{6}$ Rumen degradable protein balance (CVB, 2008).

${ }^{7} \mathrm{NE}_{\mathrm{L}}$ calculated with the VEM system (CVB, 2008).

respectively, for AA infusions. All AA were provided by Ajinomoto Animal Nutrition Europe (Paris, France) and Ajinomoto Omnichem (Wetteren, Belgium) with the exception of DL-Met, which was provided by Adisseo France (Malicorne, France). Treatment solutions were administered in 15 - $\mathrm{L}$ batches that were replenished daily and infused via multi-channel peristaltic pumps at a rate of $10.4 \mathrm{~mL} / \mathrm{min}$ to facilitate 120 -h of continuous infusion $(0900 \mathrm{~h}$ on d 1 until $0900 \mathrm{~h}$ on d 6 of each experimental period; Figure 1).

\section{Measurements and Sample Collection}

Energy and $\mathrm{N}$ balance and ATTD were based on manure and feces collection from d $3(1000 \mathrm{~h})$ through d 6 (0900 h; balance period; Figure 1), whereas $\mathrm{O}_{2}$ consumption and $\mathrm{CO}_{2}$ and $\mathrm{CH}_{4}$ production were based on data recorded from d $4(0800 \mathrm{~h})$ through d $6(0800 \mathrm{~h})$ of each experimental period. Each CRC compartment was cleaned at $0900 \mathrm{~h}$ on $\mathrm{d} 3$ (taking approximately 60 $\mathrm{min}$ ) to remove all manure collected from the end of the previous period to facilitate a fresh total collection period. At the end of each balance period (which corresponded with the end of the infusion period), cows were weighed. The manure from each compartment produced during the 71-h balance period was separate- ly and quantitatively collected, weighed, and mixed. Manure samples were collected and stored at $-20^{\circ} \mathrm{C}$ until analysis. In addition, to quantify contribution of $\mathrm{N}$ from volatilized ammonia appearing from excreted and mixed urine and feces, samples of condensed water from the chamber heat exchanger and from $25 \%$ sulfuric acid solution (wt/wt), through which outflowing air was led to trap aerial ammonia, were collected from each CRC compartment. These samples were stored at $4^{\circ} \mathrm{C}$ until analysis. During the balance period, feces was collected by rectal grab sampling at 0530 and $1530 \mathrm{~h}$ (6 samples) and immediately pooled into a composite sample by cow, which was stored at $-20^{\circ} \mathrm{C}$ until analysis. Feed refusals, when present, were collected during the balance period and stored at $4^{\circ} \mathrm{C}$. After each balance period they were pooled by cow, sampled, and stored at $-20^{\circ} \mathrm{C}$ until analysis.

Cows were milked twice daily at 0530 and $1530 \mathrm{~h}$ during the adaptation and experimental periods. Milk weight was recorded at each milking, and samples were collected at each milking into tubes containing sodium azide and stored at $4^{\circ} \mathrm{C}$ until analysis within $4 \mathrm{~d}$. An additional milk sample $(5 \mathrm{~g} / \mathrm{kg}$ of milk) was collected separately and pooled by cow at each milking during the balance period (6 milkings) and stored at $-20^{\circ} \mathrm{C}$ until gross energy (GE) and $\mathrm{N}$ analyses. Samples of 
Table 2. Dry matter intake and digestible EAA supply from the diet, and gross energy (GE), N, and EAA supply from infusions

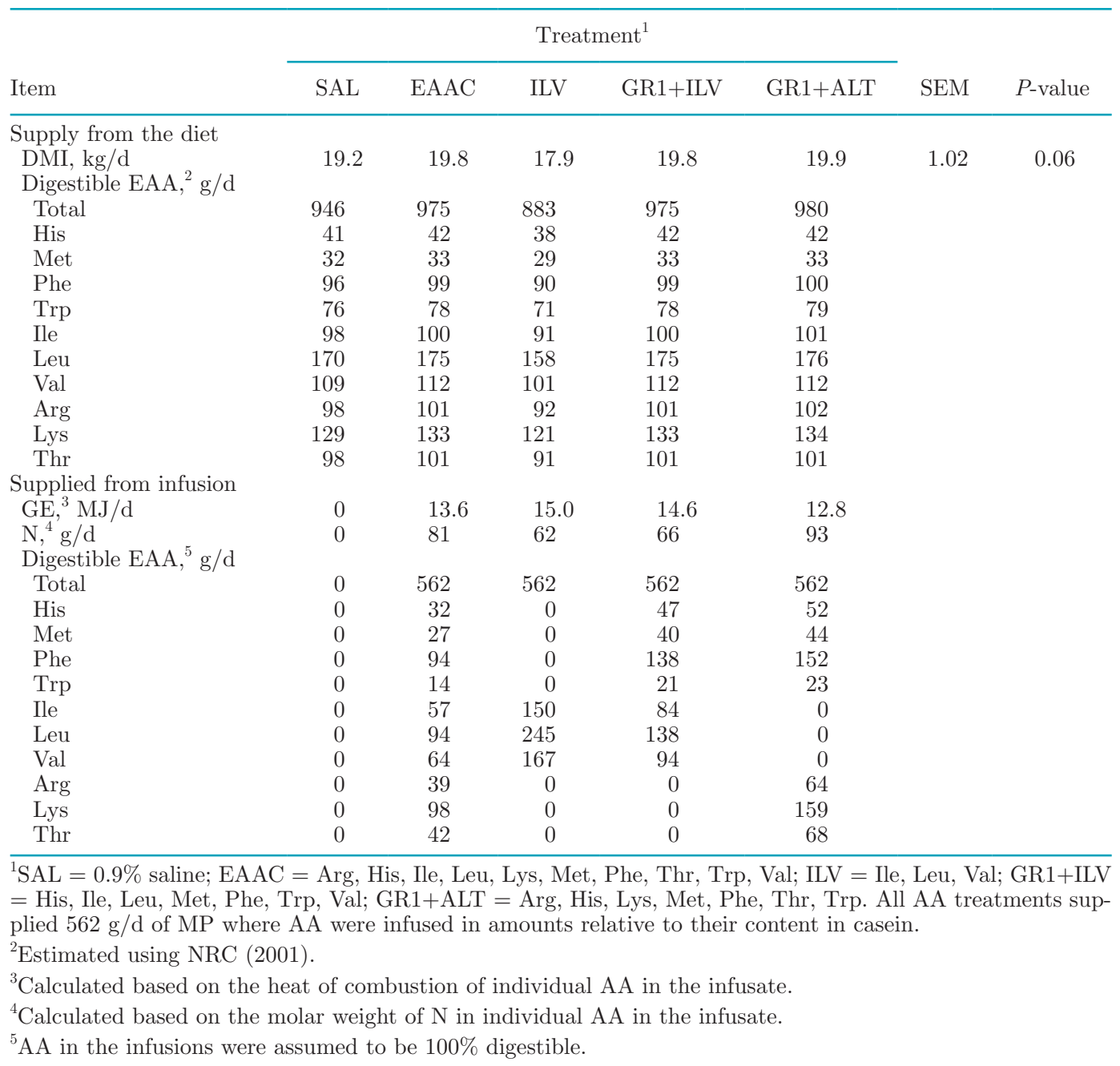

corn silage, alfalfa hay, and concentrate were collected twice weekly during feed preparation. These samples were pooled per experimental period and stored at $-20^{\circ} \mathrm{C}$ until analysis. On d 4 of each experimental period, blood samples were collected by venipuncture from the coccygeal vessels into $10 \mathrm{~mL}$ of sodium heparin and potassium EDTA Vacutainers (Becton Dickinson, Rutherford, NJ) at 0730, 0930, 1130, 1330, and 1530 h. After each sampling point, collection tubes were immediately placed in ice and centrifuged at $3,000 \times g$ at room temperature for $15 \mathrm{~min}$. Plasma was pooled over sampling time points by cow and period and stored at $-20^{\circ} \mathrm{C}$ until analysis.

\section{Analytical Procedures}

Samples of corn silage, alfalfa hay, concentrate, manure, and feces were thawed at room temperature, oven-dried at $60^{\circ} \mathrm{C}$ until a constant weight was reached, and ground to pass a 1-mm screen using a Wiley mill (Peppink 100AN, Olst, the Netherlands). Wet chemical analysis for DM, ash, $\mathrm{N}, \mathrm{NH}_{3}$, crude fat, starch, sugars, $\mathrm{NDF}, \mathrm{ADF}, \mathrm{ADL}$, and titanium was performed as described by Nichols et al. (2018). Crude protein content was calculated as total analyzed $\mathrm{N} \times 6.25$. An adiabatic bomb calorimeter (IKA-C700, Janke and Kunkel, Heitersheim, Germany) was used for determination of GE content (ISO 9831; ISO, 1998). Corn silage, alfalfa hay, and concentrate samples were analyzed for DM, ash, N, crude fat, starch (except alfalfa hay), sugars (except corn silage), NDF, ADF, ADL, GE, and titanium (concentrate only). Samples of refused feed were analyzed for DM. Manure samples were analyzed for DM, N, and GE. Feces samples were analyzed for DM, ash, N, crude fat, starch, NDF, GE, and titanium. In addition, samples of condensed water and the sulfuric acid solution were analyzed for N. Reported values for nutrient content of the TMR were calculated from 
ration composition and analyzed values obtained for the roughage and concentrate. The $\mathrm{NE}_{\mathrm{L}}$ was calculated with the VEM (feed unit lactation) system according to Van Es (1978). Reported DVE (intestinal digestible protein), OEB (rumen degradable protein balance), and $\mathrm{NE}_{\mathrm{L}}$ were obtained by near-infrared spectroscopy analysis for corn silage and alfalfa hay (Eurofins Agro, Wageningen, the Netherlands). For the concentrate, DVE, OEB, and $\mathrm{NE}_{\mathrm{L}}$ were calculated based on table values for composition of the ingredients (CVB, 2008). For the TMR, these were calculated from ration composition of all roughage and concentrate ingredients.

Milk samples from each morning and afternoon milking were analyzed separately for protein, fat, lactose, and urea by mid-infrared spectroscopy (ISO 9622; ISO, 2013; VVB, Doetinchem, the Netherlands). Pooled milk samples were analyzed for GE and $\mathrm{N}$ in fresh material as described above. Blood plasma was analyzed by the Veterinary Diagnostic Laboratory (Utrecht University, the Netherlands) on a Unicel DxC 600 analyzer (Beckman Instruments B.V., Mijdrecht, the Netherlands) for glucose (kit no. OSR6121, Beckman Coulter B.V., Woerden, the Netherlands), triacylglycerides (TAG; kit no. OSR60118, Beckman Coulter B.V.), urea (kit no. OSR6134 kit, Beckman Coulter B.V.), nonesterified fatty acids (NEFA; kit no. FA11, Randox Laboratories Ltd., Crumlin, UK), BHB (Ranbut kit, Randox Laboratories Ltd.), and insulin using an Immulite 2000 system (kit no. L2KIN2, Siemens Healthcare GmbH, Erlangen, Germany).

\section{Calculations and Statistical Analysis}

Heat production $(\mathrm{kJ} / \mathrm{d})$ was calculated as $16.175 \times$ $\mathrm{VO}_{2}(\mathrm{~L} / \mathrm{d})+5.021 \times \mathrm{VCO}_{2}(\mathrm{~L} / \mathrm{d})$, where $\mathrm{VO}_{2}$ and $\mathrm{VCO}_{2}$ are volumes of $\mathrm{O}_{2}$ consumed and $\mathrm{CO}_{2}$ produced, respectively (Gerrits et al., 2015). Apparent total-tract digestibility was calculated considering the nutrient inflow from the diet and the treatment infusions. The infusion treatments contributed DM, ash, OM, CP, and GE. Dry matter of the infusions consisted of the infusion ingredients (assumed to the 100\% DM), ash from the saline $(99 \mathrm{~g} / \mathrm{d}$ of $\mathrm{NaCl}$ ), and EAA infusions and hydroxide from mixing the AA solutions $(77 \mathrm{~g} / \mathrm{d}$ of $\mathrm{NaOH}$ and $50 \mathrm{~g} / \mathrm{d}$ of $\mathrm{HCl}$ were used to facilitate EAA mixing). Nitrogen content of the infusions was calculated based on the molar weight of $\mathrm{N}$ in individual AA in the infusate. The GE content of the AA infusions were calculated based on the heat of combustion of individual AA in the infusate, and digestibility of all infusions was assumed to be $100 \%$.

Milk yield, milk composition, and DMI were averaged over the 3 -d balance period. One cow did not receive the correct treatment in period 1 and was thus removed from the statistical analysis for this period $(\mathrm{n}=4$ for GR1+ALT; $\mathrm{n}=5$ for all other treatments). Variances in lactation performance, energy, and $\mathrm{N}$ balance, digestibility, and plasma constituents were analyzed using the MIXED procedure of SAS (version 9.4; SAS Institute Inc., Cary, NC). The model contained treatment and period as fixed effects and cow as a random effect. We observed no carryover effects between periods, assessed by testing for an effect of the previous treatment in the ANOVA. Differences were considered significant at $P \leq 0.05$ and tendencies at $0.05<P \leq 0.10$. Multiple comparisons between treatment means were made using the Tukey-Kramer method.

\section{RESULTS}

\section{DMI, Milk Production, and Digestibility}

Infusion of ILV tended to decrease DMI compared with EAAC, GR1+ILV, and GR1+ALT $(P=0.10$; Table 2). Infusion of EAAC increased milk yield and FPCM yield by 5.0 and $3.4 \mathrm{~kg} / \mathrm{d}$, respectively, over SAL $(P \leq 0.03$; Table 3$)$. Similarly, GR1+ILV increased milk yield and FPCM yield by 5.0 and 3.6 $\mathrm{kg} / \mathrm{d}$, respectively, over SAL $(P \leq 0.03)$. Milk fat yield was not affected by treatment $(P=0.52)$, but ILV increased milk fat concentration over EAAC $(P=0.04)$. Milk protein yield did not differ between ILV and SAL $(P>0.10)$, but decreased with ILV infusion compared with EAAC and GR1+ILV $(P \leq 0.02)$. Infusion of EAAC and GR1+ILV increased milk protein yield by 224 and $187 \mathrm{~g} / \mathrm{d}$, respectively, over SAL $(P \leq 0.02)$. Infusion of ILV decreased milk protein concentration by $10 \%$ compared with EAAC $(P=0.03)$. The ratio between protein and fat content in milk was not different between SAL and ILV $(P=0.87)$, and increased with EAAC infusion compared with SAL $(P=0.03)$. The ratio decreased with ILV infusion compared with EAAC $(P=0.01)$, and tended to decrease with ILV infusion compared with GR1+ILV $(P=0.06)$. Milk lactose yield was not different between SAL and ILV $(P>0.10)$, but increased by an average of $188 \mathrm{~g} / \mathrm{d}$ over SAL when EAAC, GR1+ILV, or GR1+ALT were infused $(P=0.05)$. Infusion of ILV increased lactose concentration by 0.16 units compared with EAAC and GR1+ILV $(P \leq 0.02)$. Milk urea concentration was not affected by treatment $(P=0.41)$.

Apparent total-tract digestibility of DM and OM was higher on ILV infusion compared with GR1+ALT ( $P=$ 0.04; Table 4). All AA infusions increased CP digestibility compared with SAL (12\% increase on average; $P$ $<0.01)$. Starch digestibility tended to be higher with ILV compared with SAL $(P=0.06)$ and GR1+ALT $(P=0.09)$. Gross energy digestibility was higher with 
Table 3. Milk production and composition of lactating dairy cows receiving abomasal infusions of saline or $562 \mathrm{~g} / \mathrm{d}$ of AA in different profiles for $5 \mathrm{~d}^{1}$

\begin{tabular}{|c|c|c|c|c|c|c|c|}
\hline \multirow[b]{2}{*}{ Item } & \multicolumn{5}{|c|}{ Treatment $^{2}$} & \multirow[b]{2}{*}{ SEM } & \multirow[b]{2}{*}{$P$-value } \\
\hline & SAL & EAAC & ILV & GR1+ILV & GR1+ALT & & \\
\hline Milk, $\mathrm{kg} / \mathrm{d}$ & $29.4^{\mathrm{a}}$ & $34.4^{\mathrm{b}}$ & $30.8^{\mathrm{ab}}$ & $34.4^{\mathrm{b}}$ & $33.3^{\mathrm{ab}}$ & 2.00 & 0.01 \\
\hline Fat, $\mathrm{g} / \mathrm{d}$ & 1,247 & 1,281 & 1,315 & 1,321 & 1,273 & 62.3 & 0.52 \\
\hline Protein, g/d & $902^{\mathrm{a}}$ & $1,126^{\mathrm{b}}$ & $907^{\mathrm{a}}$ & $1,089^{\mathrm{b}}$ & $1,034^{\mathrm{ab}}$ & 51.8 & $<0.01$ \\
\hline Lactose, $\mathrm{g} / \mathrm{d}$ & $1,385^{\mathrm{a}}$ & $1,581^{\mathrm{b}}$ & $1,463^{\mathrm{ab}}$ & $1,575^{\mathrm{b}}$ & $1,563^{\mathrm{b}}$ & 89.2 & 0.03 \\
\hline Protein & $3.08^{\mathrm{ab}}$ & $3.28^{\mathrm{a}}$ & $2.95^{\mathrm{b}}$ & $3.18^{\mathrm{ab}}$ & $3.14^{\mathrm{ab}}$ & 0.099 & 0.04 \\
\hline Lactose & $4.70^{\mathrm{ab}}$ & $4.60^{\mathrm{b}}$ & $4.75^{\mathrm{a}}$ & $4.59^{\mathrm{b}}$ & $4.69^{\mathrm{ab}}$ & 0.038 & 0.01 \\
\hline Protein:fat ${ }^{3}$ & $0.72^{\mathrm{a}}$ & $0.88^{\mathrm{b}}$ & $0.68^{\mathrm{a}}$ & $0.81^{\mathrm{ab}}$ & $0.80^{\mathrm{ab}}$ & 0.055 & 0.01 \\
\hline $\mathrm{FPCM},{ }^{4} \mathrm{~kg} / \mathrm{d}$ & $30.1^{\mathrm{a}}$ & $33.5^{\mathrm{b}}$ & $31.3^{\mathrm{ab}}$ & $33.7^{\mathrm{b}}$ & $32.5^{\mathrm{ab}}$ & 1.29 & 0.02 \\
\hline Milk urea, mg/dL & 11.2 & 11.2 & 11.2 & 12.8 & 13.5 & 2.03 & 0.41 \\
\hline
\end{tabular}

${ }^{\mathrm{a}, \mathrm{b}}$ Means within a row with no common superscripts differ $(P<0.05)$.

${ }^{1}$ Data are LSM from the final $3 \mathrm{~d}$ of infusion.

${ }^{2} \mathrm{SAL}=0.9 \%$ saline; EAAC $=$ Arg, His, Ile, Leu, Lys, Met, Phe, Thr, Trp, Val; ILV = Ile, Leu, Val; GR1+ILV = His, Ile, Leu, Met, Phe, Trp, Val; GR1+ALT $=$ Arg, His, Lys, Met, Phe, Thr, Trp. All AA treatments supplied $562 \mathrm{~g} / \mathrm{d}$ of MP where AA were infused in amounts relative to their content in casein.

${ }^{3}$ Protein $\% \div$ fat $\%$.

${ }^{4}$ Fat- and protein-corrected milk $(\mathrm{FPCM} ; \mathrm{kg} / \mathrm{d})=(0.337+0.116 \times$ fat $\%+0.06 \times$ protein $\%) \times$ milk yield $(\mathrm{kg} / \mathrm{d})(\mathrm{CVB}, 2008)$.

ILV compared with SAL $(P=0.03)$ and GR1+ALT $(P$ $=0.04)$. Digestibility of NDF and crude fat were not affected by treatment $(P>0.27)$.

\section{Energy and N Balance}

Metabolic BW was not affected by treatment $(P=$ 0.24; Table 5). Total GE intake was not different between AA infusions and $\operatorname{SAL}(P \geq 0.30)$, but tended to be decreased by ILV infusion compared with EAAC $(P=0.07)$ and GR1+ILV $(P=0.10)$. Energy output in manure and daily $\mathrm{CH}_{4}$ production were not affected by treatment $(P \geq 0.50)$. Metabolizable energy intake
(MEI) was lower with ILV compared with EAAC $(P$ $=0.03$ ) , and tended to be lower with ILV compared with GR1+ILV $(P=0.08)$ and GR1+ALT $(P=0.10)$. The ratio of MEI to GE intake was not affected by treatment $(P=0.42)$. All AA infusions tended to increase heat production compared with SAL $(P=0.07)$. Compared with SAL, energy output in milk increased with EAAC $(P=0.02)$ and tended to increase with GR1+ILV $(P=0.06)$. Infusion of ILV tended to decrease milk energy output compared with EAAC $(P$ $=0.10)$. Total energy retention $(\mathbf{E R})$ and ER in fat decreased with ILV compared with SAL $(P \leq 0.05)$. Infusion of EAAC increased and tended to increase ER

Table 4. Apparent total-tract digestibility (\%) of nutrients in lactating dairy cows receiving abomasal infusions of saline or $562 \mathrm{~g} / \mathrm{d}$ of AA in different profiles for $5 \mathrm{~d}^{1}$

\begin{tabular}{|c|c|c|c|c|c|c|c|}
\hline \multirow[b]{2}{*}{ Item } & \multicolumn{5}{|c|}{ Treatment $^{2}$} & \multirow[b]{2}{*}{ SEM } & \multirow[b]{2}{*}{$P$-value } \\
\hline & SAL & EAAC & ILV & GR1+ILV & GR1+ALT & & \\
\hline DM & $67.8^{\mathrm{ab}}$ & $67.3^{\mathrm{ab}}$ & $68.9^{\mathrm{a}}$ & $68.3^{\mathrm{ab}}$ & $66.4^{\mathrm{b}}$ & 0.97 & 0.05 \\
\hline $\mathrm{OM}$ & $69.3^{\mathrm{ab}}$ & $68.8^{\mathrm{ab}}$ & $70.4^{\mathrm{a}}$ & $69.9^{\mathrm{ab}}$ & $67.9^{\mathrm{b}}$ & 0.98 & 0.05 \\
\hline $\mathrm{CP}$ & $62.0^{\mathrm{a}}$ & $70.8^{\mathrm{b}}$ & $69.9^{\mathrm{b}}$ & $68.4^{\mathrm{b}}$ & $69.8^{\mathrm{b}}$ & 0.90 & $<0.01$ \\
\hline NDF & 43.1 & 42.3 & 45.2 & 44.4 & 40.3 & 2.28 & 0.27 \\
\hline Crude fat & 71.2 & 72.7 & 71.6 & 70.6 & 71.9 & 0.98 & 0.59 \\
\hline Starch & 97.4 & 97.5 & 98.3 & 97.5 & 97.4 & 0.38 & 0.05 \\
\hline $\mathrm{GE}^{3}$ & $66.7^{\mathrm{a}}$ & $67.4^{\mathrm{ab}}$ & $69.3^{\mathrm{b}}$ & $68.5^{\mathrm{ab}}$ & $66.6^{\mathrm{a}}$ & 0.88 & 0.02 \\
\hline
\end{tabular}

${ }_{\mathrm{a}, \mathrm{b}}$ Means within a row with no common superscripts differ $(P<0.05)$.

${ }^{1}$ Data are LSM calculated from feed and feces sampled during the final $3 \mathrm{~d}$ of infusion and were calculated considering the total nutrient inflow from the diet + infusions.

${ }^{2} \mathrm{SAL}=0.9 \%$ saline; EAAC $=$ Arg, His, Ile, Leu, Lys, Met, Phe, Thr, Trp, Val; ILV = Ile, Leu, Val; GR1+ILV $=$ His, Ile, Leu, Met, Phe, Trp, Val; GR1+ALT = Arg, His, Lys, Met, Phe, Thr, Trp. All AA treatments supplied $562 \mathrm{~g} / \mathrm{d}$ of MP where AA were infused in amounts relative to their content in casein.

${ }^{3} \mathrm{GE}=$ gross energy. 
Table 5. Energy and nitrogen balance of lactating dairy cows receiving abomasal infusions of saline or $562 \mathrm{~g} / \mathrm{d}$ of AA in different profiles for $5 \mathrm{~d}$

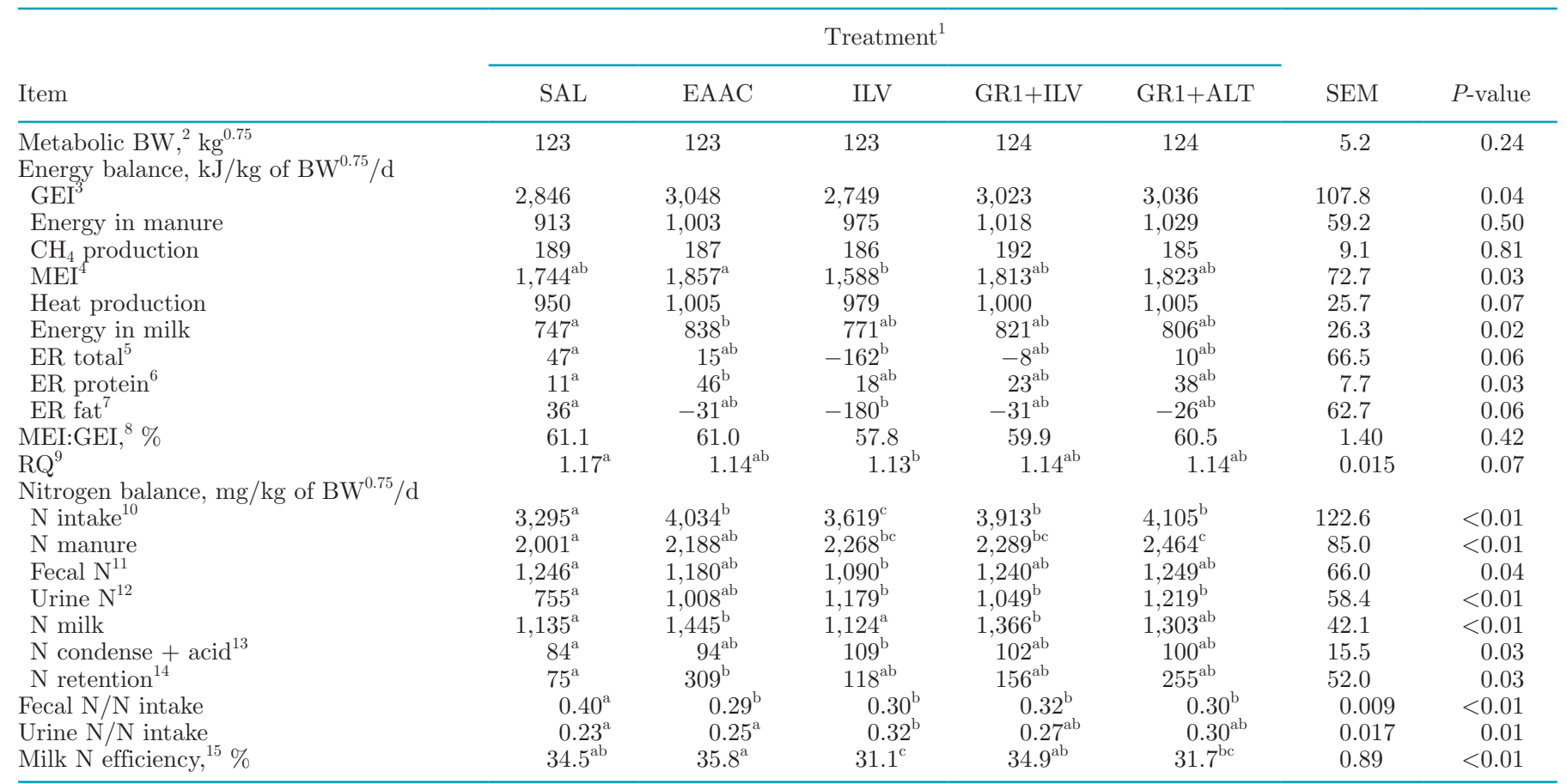

${ }^{\mathrm{a}-\mathrm{c}}$ Means within a row with no common superscripts differ $(P<0.05)$.

${ }^{1} \mathrm{SAL}=0.9 \%$ saline; EAAC $=$ Arg, His, Ile, Leu, Lys, Met, Phe, Thr, Trp, Val; ILV = Ile, Leu, Val; GR1+ILV = His, Ile, Leu, Met, Phe, Trp, Val; GR1+ALT = Arg, His, Lys, Met, Phe, Thr, Trp. All AA treatments supplied $562 \mathrm{~g} / \mathrm{d}$ of MP where AA were infused in amounts relative to their content in casein.

${ }^{2}$ The mean BW per cow per balance period was used to calculate metabolic BW $\left(\mathrm{BW}^{0.75}\right)$.

${ }^{3} \mathrm{GEI}=$ gross energy intake (diet + infusions).

${ }^{4}$ Metabolizable energy intake $=$ GEI - methane production - energy in manure.

${ }^{5}$ Energy retention total $=$ MEI - heat production - energy in milk.

${ }^{6}$ Energy retention protein $=$ protein gain $(\mathrm{N} \times 6.25) \times 3.6 \mathrm{~kJ} / \mathrm{g}$ (energetic value of body protein $)$.

${ }^{7}$ Energy retention fat $=$ energy retention total - energy retention protein.

${ }^{8} \mathrm{MEI}$ GEI $=$ ratio between MEI and GEI.

${ }^{9}$ Respiratory quotient.

${ }^{10}$ Diet + infusions.

${ }^{11}$ Fecal $\mathrm{N}=\mathrm{N}$ intake $\times[1-(\mathrm{CP}$ digestibility/100) $]$.

${ }^{12}$ Urine $\mathrm{N}=\mathrm{N}$ manure - fecal $\mathrm{N}$.

${ }^{13} \mathrm{~N}$ from condensed water collected from heat exchanger $+\mathrm{N}$ trapped from outflowing air.

${ }^{14} \mathrm{~N}$ retention $=\mathrm{N}$ intake (including infusate $\left.\mathrm{N}\right)-\mathrm{N}$ manure $-\mathrm{N}$ milk $-\mathrm{N}$ condense + acid.

${ }^{15}$ Milk $\mathrm{N}$ efficiency $=(\mathrm{N}$ milk $/ \mathrm{N}$ intake $) \times 100$.

in protein compared with SAL $(P=0.03)$ and ILV $(P$ $=0.09)$, respectively. The respiratory quotient $(\mathbf{R Q})$ decreased with ILV compared with SAL $(P=0.04)$, but did not differ across AA infusions $(P>0.60)$.

Nitrogen intake increased with all AA infusions compared with SAL $(P \leq 0.02)$, but was lower with ILV infusion compared with EAAC, GR1+ILV, and GR1+ALT $(P \leq 0.04)$. Manure $\mathrm{N}$ output was higher with ILV, GR1+ILV, and GR1+ALT infusions compared with SAL $(P \leq 0.02)$, and was higher with GR1+ALT infusion compared with EAAC $(P=0.02)$. Infusion of ILV decreased fecal N output compared with SAL $(P=0.05)$, and tended to decrease it compared with $\operatorname{GR} 1+\operatorname{ILV}(P=0.06)$ and $\operatorname{GR} 1+\operatorname{ALT}(P=0.07)$. The proportion of $\mathrm{N}$ intake excreted in feces decreased with all AA infusions compared with SAL $(P<0.01)$. Urine N output was higher with ILV, GR1+ILV, and GR1+ALT $(P \leq 0.03)$, and tended to be higher with EAAC $(P=0.06)$, compared with SAL. The proportion of $\mathrm{N}$ intake excreted in urine increased over SAL and EAAC with ILV infusion $(P \leq 0.04)$, and tended to increase over SAL with GR1+ALT $(P=0.10)$. Milk N output increased with EAAC and GR1+ILV $(P \leq 0.01)$ and tended to increase with GR1+ALT $(P=0.10)$ compared with SAL. Milk N output on ILV infusion was lower compared with EAAC and GR1+ILV $(P \leq 0.01)$ 
and tended to be lower than GR1+ALT $(P=0.08)$. Nitrogen trapped in condensed water and air increased with ILV compared with SAL $(P=0.02)$. Nitrogen retention increased with EAAC compared with SAL $(P=$ $0.03)$, and tended to decrease with ILV compared with EAAC $(P=0.09)$. Milk $\mathrm{N}$ efficiency was not different between SAL, EAAC, and GR1+ILV $(P>0.70)$. Milk $\mathrm{N}$ efficiency decreased with ILV infusion compared with SAL, EAAC, and GR1+ILV $(P \leq 0.03)$. Infusion of GR1+ALT decreased milk N efficiency compared with EAAC $(P=0.02)$ and tended to decrease it compared with GR1+ILV $(P=0.08)$.

\section{Plasma Constituents}

Arterial plasma concentrations of glucose, BHB, NEFA, and TAG were not affected by AA infusions $(P$ $\geq 0.49$; Table 6 ). Plasma urea concentration increased with GR1+ALT compared with SAL and EAAC $(P \leq$ $0.05)$, and tended to increase over SAL with ILV $(P=$ $0.08)$ and GR1+ILV $(P=0.06)$. Plasma insulin concentration tended to decreased with EAAC compared with SAL $(P=0.06)$, and decreased with EAAC compared with GR1+ILV $(P=0.05)$. Infusion of ILV decreased plasma insulin concentration compared with SAL and GR1+ILV $(P<0.01)$.

\section{DISCUSSION}

The aim of this study was to determine the effect of AA profile within a constant MP supply on milk production and whole-body energy and N partitioning. The fact that the infused MP level was kept constant across AA treatments in this study is an important difference compared with others testing subtractions of individual AA or groups of AA (Weekes et al., 2006; Doelman et al., 2015a,b; Lapierre et al., 2009). The AA infusions were iso-MP, thus they were not isoenergetic or isoni- trogenous, and the absolute amount of each individual AA infused differed with each treatment (Table 2). The present experimental design does not allow evaluation of linear or quadratic effects of doses of individual AA. We chose this approach to facilitate investigation of potential compensation between certain EAA groups in the presence or absence of other EAA groups, and the resulting effect on energy and $\mathrm{N}$ balance. Metabolizable protein intake from the diet plus infusion of EAAC, GR1+ILV, or GR1+ALT supplied 107, 111, and 117\%, respectively, of calculated MP requirements based on observed DMI and milk production (CVB, 2008). These AA infusions increased total MP supply by $138 \%$ over SAL. Based on MP intake from the infusion and the observed DMI and milk production on ILV infusion, this treatment supplied $125 \%$ of MP requirements and increased MP supply by $132 \%$ over SAL.

Increased ATTD of CP in response to AA infusions can be attributed to greater digestibility of the infused AA compared with the basal diet, as this effect disappeared when ATTD was calculated considering only intake of the basal diet (data not shown). If the CP digestibility of $62 \%$ observed with SAL represents CP digestibility of the basal diet, calculated ATTD of the infused AA was $111,103,98$, and $106 \%$ on EAAC, ILV, GR1+ILV, and GR1+ALT, respectively. These estimates of ATTD support our assumption that the infused AA would be $100 \%$ digestible, and suggest that AA transport and absorption in the intestine was not inhibited when relatively high levels of individual AA were supplied in the incomplete EAA infusions.

\section{Complete EAA Infusion Increased Milk Protein Synthesis Without Decreasing Milk N Efficiency}

The complete EAA profile in this experiment was intended as a positive control with which to compare the responses stimulated by the incomplete EAA profiles.

Table 6. Arterial plasma concentrations of metabolites and insulin in lactating dairy cows receiving abomasal infusions of saline or $562 \mathrm{~g} / \mathrm{d}$ of AA in different profiles for $5 \mathrm{~d}$

\begin{tabular}{|c|c|c|c|c|c|c|c|}
\hline \multirow[b]{2}{*}{ Item } & \multicolumn{5}{|c|}{ Treatment $^{1}$} & \multirow[b]{2}{*}{ SEM } & \multirow[b]{2}{*}{$P$-value } \\
\hline & SAL & EAAC & ILV & GR1+ILV & GR1+ALT & & \\
\hline Glucose, $\mathrm{m} M$ & 3.64 & 3.64 & 3.58 & 3.36 & 3.71 & 0.140 & 0.49 \\
\hline $\mathrm{BHB}, \mathrm{m} M$ & 0.76 & 0.90 & 0.84 & 0.95 & 0.78 & 0.122 & 0.74 \\
\hline $\mathrm{NEFA}^{2}, \mu M$ & 64 & 74 & 86 & 68 & 80 & 16.1 & 0.78 \\
\hline $\mathrm{TAG},{ }^{2} \mu M$ & 66 & 66 & 58 & 66 & 65 & 4.1 & 0.51 \\
\hline Urea, $\mathrm{m} M$ & $2.26^{\mathrm{a}}$ & $2.50^{\mathrm{a}}$ & $2.78^{\mathrm{ab}}$ & $2.80^{\mathrm{ab}}$ & $3.12^{\mathrm{b}}$ & 0.239 & 0.01 \\
\hline Insulin, mIU/L & $20.5^{\mathrm{ab}}$ & $16.3^{\mathrm{bc}}$ & $13.8^{\mathrm{c}}$ & $20.6^{\mathrm{a}}$ & $16.9^{\mathrm{abc}}$ & 3.00 & $<0.01$ \\
\hline
\end{tabular}


In previous experiments feeding low-CP diets (11-14\%) to cows, postruminal infusion of $562 \mathrm{~g} / \mathrm{d}$ of EAA in the profile of casein resulted in an average increase of 3.2 $\mathrm{kg} / \mathrm{d}$ of total milk and $164 \mathrm{~g} / \mathrm{d}$ of milk protein compared with a saline control (Doelman et al., 2015a,b). Infusion of 1.5 times this EAA dose resulted in an average increase of $3.7 \mathrm{~kg} / \mathrm{d}$ of total milk and $221 \mathrm{~g} / \mathrm{d}$ of milk protein compared with a saline control (Nichols et al., 2016, 2019). In the current experiment, the $562 \mathrm{~g} / \mathrm{d}$ dose was used to illicit a clear response, while avoiding potentially too-high levels of individual AA in the incomplete infusions. As expected, EAAC increased the yield of total milk, protein, and lactose. Infusion of the complete EAA profile resulted in a 35\% marginal use efficiency of infused EAA for milk protein synthesis. This value describes the efficiency with which each unit of total supplemented EAA is used for milk protein synthesis. The marginal use efficiency of infused AA was calculated based on the incremental milk protein yield achieved by the infused EAA, after correcting for the milk protein yield allowed by the $0.6-\mathrm{kg} / \mathrm{d}$ extra feed intake during EAAC infusion; the latter was estimated based on the milk protein efficiency ( $\mathrm{g}$ of milk protein per $\mathrm{g}$ of feed protein) observed on SAL. This value is greater than the predicted $25 \%$ marginal use of casein if infused in the same $562 \mathrm{~g} / \mathrm{d}$ dose (Huhtanen and Hristov, 2010), and the marginal use of the same EAA profile infused at 1.5 times this dose calculated from reports by Nichols et al. (2016) and Nichols et al. (2019), which ranged from 22 to $30 \%$. Compared with casein, marginal efficiency is expected to be greater with EAA infusion, as NEAA in casein offer little toward increases in milk protein synthesis (Metcalf et al., 1996; Doepel and Lapierre, 2010). It also appears that when supplemented in a casein profile, EAA use can become more efficient at a lower dose than at a higher dose.

Infusion of EAA, regardless of profile, tended to increase heat production. Biological transformation of $\mathrm{N}$ molecules is associated with energy loss, particularly during ureagenesis from excess N (Martin and Blaxter, 1965). Based on the estimation of Reed et al. (2017) that 3.3 MJ of heat is produced per $\mathrm{kg}$ of RUP, metabolism of $562 \mathrm{~g} / \mathrm{d}$ of infused AA (representing 100\% RUP) would produce $15 \mathrm{~kJ} / \mathrm{kg}$ of $\mathrm{BW}^{0.75} / \mathrm{d}$ of heat. This accounts for $34 \%$ of the average increase in heat production with EAA infusions over SAL. The lower RQ relative to SAL during EAA infusions suggests a portion of AA were catabolized for energy generation. These findings are in line with Nichols et al. (2019) who reported a contribution to the incremental increase in heat production of $32 \%$ from metabolism of $844 \mathrm{~g} / \mathrm{d}$ of abomasally infused EAA, and a drop in RQ from on average 1.12 without EAA infusion to 1.10 with EAA infusion.

Milk $\mathrm{N}$ output increased with the extra $\mathrm{N}$ intake on EAAC, resulting in the same milk $\mathrm{N}$ efficiency between EAAC and SAL. Manure N output was not affected, but $\mathrm{N}$ excretion tended to shift toward urine, which is in line with generally higher output of $\mathrm{N}$ in urine compared with feces as $\mathrm{N}$ intake increases (Dijkstra et al., 2013) and can be explained by the high intestinal digestibility of infused EAA. A larger portion of $\mathrm{N}$ intake was retained in the body during EAAC infusion compared with SAL, and consequently energy deposited as body protein also increased. Body $\mathrm{N}$ retention reported here is in line with Nichols et al. (2019) in response to EAA infusion in the same AA profile, and with others who supplied postruminal AA to mid-lactation cows (Clark et al., 1977; Wright et al., 1998; Castillo et al., 2001). Overall, EAAC infusion illustrated the positive effects of supplemented MP in a complete EAA profile with respect to casein on milk protein production and milk $\mathrm{N}$ efficiency. It therefore serves, as planned, as a positive control when reflecting on the efficacy of incomplete EAA profiles at the same level of MP supply.

\section{Infusion of ILV Induced an AA Imbalance and Reduced Milk N Efficiency}

In line with our hypothesis, milk production and whole-body energy and $\mathrm{N}$ balance differed most dramatically in response to ILV infusion compared with EAAC. Compared with the other AA infusions, ILV tended to decrease DMI by $1.9 \mathrm{~kg} / \mathrm{d}$. Under conditions of imbalanced AA intake, especially in low protein diets, feed intake depression is a homeostatic adaptation against a diet that is incompatible with maintenance of protein synthesis and regulation of AA concentrations in body fluids (Harper et al., 1970; Gietzen et al., 2007). In animals infused with imbalanced AA profiles, this response would be reflected in reduced intake of the basal diet. The severity of AA imbalance in a diet influences the magnitude and duration of observed hypophagic effects (Harper et al., 1970; Gietzen, 1993). With ILV infusion, Ile, Leu, and Val were delivered at levels 2.6 times those in EAAC, and to our knowledge, these infusion amounts in $\mathrm{g} / \mathrm{d}$ are higher than any reported previously in lactating ruminants. In the GR1+ILV and GR1+ALT infusions, the imbalances were relatively less severe, with AA present in 1.5 and 1.6 times the amount as in EAAC, respectively. Therefore, the severity of the AA imbalance induced with ILV infusion may explain the observed hypophagic effect, and may explain why no difference in DMI in response to GR1+ILV and GR1+ALT infusions was observed. 
Despite the $1.3 \mathrm{~kg} / \mathrm{d}$ lower DMI compared with SAL, infusion of ILV produced the same yield of total milk, protein, fat, and lactose. Accordingly, milk energy output was not different from SAL with ILV infusion, but energy balance was negative due to lower MEI. Lower plasma insulin concentration in response to ILV compared with SAL can be attributed to the depressed DMI, which would favor increased hepatic gluconeogenesis (Brockman and Laarveld, 1986; Lobley, 1998), in agreement with the maintained arterial plasma glucose concentration between SAL and ILV. Considering the lower DMI, the decreased plasma insulin concentration, and the negative energy balance on ILV infusion, TAG mobilization from adipose might be expected. However, arterial plasma concentrations of BHB, NEFA, and TAG were not affected, suggesting substrates for gluconeogenesis arose from catabolic products of infused BCAA. In agreement with increased AA catabolism on ILV, a greater proportion of $\mathrm{N}$ intake was excreted via urine compared with SAL and EAAC, and plasma urea concentration tended to increase compared with SAL. Catabolism of AA for energy with ILV infusion also agrees with the lower RQ compared with SAL.

Extensive metabolism of BCAA in lactating ruminants occurs in the gut (MacRae et al., 1997; El-Kadi et al., 2006) and in peripheral tissues (i.e., mammary gland, skeletal muscle, and adipose; Vernon et al., 1985; Bequette et al., 2001). Glutamate produced during BCAA transamination contributes to the synthesis of other NEAA, which can be mobilized from skeletal muscle or transported from the gut and used for gluconeogenesis in the liver, or can be used in support of milk protein synthesis in the mammary gland. Increased intramammary de novo NEAA synthesis from BCAA during ILV infusion would support milk protein yield, partition circulating NEAA toward gluconeogenesis, and may spare some EAA from hepatic catabolism in favor of milk protein synthesis (Lapierre et al., 2005; Doepel and Lapierre, 2010; Nichols et al., 2016). Maintained milk fat synthesis also agrees with increased intramammary BCAA catabolism, as decarboxylated branched-chain $\alpha$-ketoacids can serve as primers for de novo synthesis of FA (Vernon et al., 1985; Crown et al., 2015). The larger increase in milk fat relative to milk protein with ILV infusion compared with SAL adds credence to the AA imbalance on ILV infusion, because in contrast to protein synthesis, FA can be produced from BCAA as a product of their catabolism without requiring other AA. This is also reflected in the lower milk protein-to-fat content ratio on ILV compared with EAAC and numerically lower protein-to-fat content ratio compared with SAL, a measure that is considered to be an indicator of dietary AA imbalance (Cant et al., 2001; Weekes et al., 2006). Overall, this evidence of a global increase in BCAA catabolism during ILV infusion agrees with the decreased milk $\mathrm{N}$ efficiency observed on ILV compared with SAL or EAAC.

Milk N efficiency was highest with SAL and EAAC and lowest with ILV, but milk urea concentration was $11.2 \mathrm{mg} / \mathrm{dL}$ with all 3 treatments. The relationship between milk urea and urinary $\mathrm{N}$ excretion is highly variable (Spek et al., 2013). In agreement with previous work where postruminal AA supply was increased (Nichols et al., 2018, 2019), milk urea concentration was not indicative of overall $\mathrm{N}$ efficiency in the current study. There are clear differences in milk $\mathrm{N}$ efficiency, manure $\mathrm{N}$ excretion, and plasma urea concentration across SAL and AA infusions, but these differences were not detected in milk urea concentration.

\section{Similar Milk Production Between EAAC, GR1+ILV, and GR1+ALT}

Whether Arg, Lys, and Thr, or Ile, Leu, and Val, were absent from a complete EAA profile, the same level of total milk, protein, fat, and lactose yield was achieved as on a complete EAA profile when the other 7 EAA were present and together delivered the same MP supply. No difference in milk or component production between EAAC and GR1+ILV supports our hypothesis that the absence of Arg, Lys, and Thr from the infusion would have minimal effects on milk protein yield. We hypothesized that the absence of the BCAA on GR1+ALT would reduce milk protein yield compared with EAAC, in line with the observations of Doelman et al. (2015b), but this was not observed. Together, these observations suggest that the negative effects of an apparent shortage of certain group $2 \mathrm{AA}$ can be prevented by increasing supply of other group 2 AA to an equal level to compensate for the deletion. This also suggests that when group $2 \mathrm{AA}$ are subtracted from AA supplements, the negative effects observed on milk protein synthesis may not necessarily be due to their status as single limiting AA as such, but due to the fact that total EAA supply becomes lower. This could be particularly relevant for Lys, where several studies show that subtracting only Lys from a complete total AA or EAA profile, when its removal is not compensated in MP supply, consistently has negative effects on milk protein yield (Fraser et al., 1991; Weekes et al., 2006; Doelman et al., 2015b).

Due to their similar dynamics with regard to mammary gland utilization, group 2 AA may have reciprocally compensated $\mathrm{N}$ and carbon for milk component synthesis when, as a group, their supply in MP was relatively low; however, the EAA themselves that were absent from the GR1+ILV and GR1+ALT infusions could not have been synthesized de novo. An exception 
is Arg, which can be produced endogenously but not in adequate amounts to meet requirements of high-producing cows (NRC, 2001; Doepel et al., 2004). To support the increase in milk protein synthesis when GR1+ILV or GR1+ALT were infused compared with SAL, either metabolism of the EAA absent from the infusions was downregulated in splanchnic and peripheral tissues, their oxidation in the mammary gland was reduced, their mobilization from endogenous sources was stimulated, or a combination of these processes occurred. Net Lys removal by the liver in dairy cows is negligible, particularly at low MP supplies and under conditions of apparent Lys deficiency (Raggio et al., 2004; Lapierre et al., 2009), so Lys catabolism was likely decreased in peripheral tissues during GR1+ILV infusion. Furthermore, hepatic Thr catabolism is flexible, and may have decreased in response to the reduced availability (Lapierre et al., 2005), and contribution from de novo Arg synthesis could have increased or its catabolism could have decreased. With GR1+ALT infusion, Ile, Leu, and Val catabolism in the mammary gland could have decreased, as a portion of their intramammary catabolism may be nonobligate (Bequette et al., 1996, 2001). Branched-chain AA also could have been mobilized from skeletal muscle, supported by the numerically lower plasma insulin concentration on GR1+ALT compared with SAL.

\section{GR1+ALT Profile Achieved Lower Milk N Efficiency than GR1+ILV and EAAC}

Compared with a complete EAA profile, supplementing the same level of MP in an EAA profile where Arg, Lys, and Thr are absent resulted in the same milk $\mathrm{N}$ efficiency, manure $\mathrm{N}$ excretion, and body $\mathrm{N}$ retention, in line with our hypothesis. In contrast, infusion of GR1+ALT resulted in increased plasma urea concentration and manure $\mathrm{N}$ output and lower milk $\mathrm{N}$ efficiency compared with a complete EAA profile. Milk $\mathrm{N}$ efficiency was 4.1 and 3.2 units lower on GR1+ALT compared with EAAC and GR1+ILV, respectively. Marginal use efficiency of infused EAA on GR1+ALT (18\%) was lower than that on EAAC (35\%), contributing to the greater proportion of $\mathrm{N}$ intake excreted in urine compared with that on EAAC. Marginal use efficiency of infused EAA in the absence of Arg, Lys, and Thr on GR1+ILV infusion was $28 \%$, which is closer to the marginal efficiency obtained with EAAC when compared with that achieved in the absence of Ile, Leu, and Val on GR1+ALT infusion.

Differences in N partitioning between GR1+ILV and GR1+ALT infusions could have been due to differences in metabolism of the group $2 \mathrm{AA}$ present in the respective infusions, and to the higher supply of group $1 \mathrm{AA}$ in the GR1+ALT infusion compared with GR1+ILV. Hepatic removal of His, Met, and Phe influences efficiency of transfer of absorbed AA into milk AA (Raggio et al., 2004). However, hepatic first-pass metabolism of His, Met, and Phe was likely unaffected by the absence of the respective group $2 \mathrm{AA}$ in the infusions because of the distinction in affinity for hepatic or peripheral catabolism between these AA groups (Lobley and Lapierre, 2003; Lapierre et al., 2005). Because there is almost no net BCAA uptake by the liver (Lapierre et al., 2002; Raggio et al., 2004), a relatively larger proportion of exogenous BCAA on GR1+ILV would have been available for mammary gland uptake, as they composed $56 \%$ of the AA in this infusion. In contrast, when the GR1+ALT profile was infused, although liver removal of Lys is usually negligible (Raggio et al., 2004; Lapierre et al., 2009), Arg and Thr may have undergone relatively more hepatic catabolism at first pass (Blouin et al., 2002; Tagari et al., 2008) compared with Ile, Leu, and Val in the GR1+ILV infusion. Furthermore, considering the fact that, relative to GR1+ILV, GR1+ALT supplied $10 \%$ more group 1 AA but produced $5 \%$ less milk protein, a greater amount of His, Met, and Phe could have been catabolized in the liver after mammary gland first pass during GR1+ALT infusion compared with GR1+ILV. The suggestion of greater hepatic catabolism of these AA is supported by the higher plasma urea concentration on GR1+ALT compared with EAAC. This is also in line with the higher marginal transfer efficiency of infused EAA on GR1+ILV (28\%) than on GR1+ALT (18\%).

\section{CONCLUSIONS}

When compared with a complete EAA profile, the same level of total milk, protein, fat, and lactose yield can be produced whether Arg, Lys, and Thr, or Ile, Leu, and Val are absent from a postruminal EAA supplement, if the other $7 \mathrm{EAA}$ are present to compensate the MP supply. Supplementing an EAA profile where Arg, Lys, and Thr were absent achieved the same level of milk $\mathrm{N}$ efficiency and $\mathrm{N}$ excretion in manure as a complete EAA profile. Absence of Ile, Leu, and Val resulted in lower milk $\mathrm{N}$ efficiency and higher manure $\mathrm{N}$ excretion compared with a complete EAA profile, and tended to result in lower milk $\mathrm{N}$ efficiency compared with the EAA profile without Arg, Lys, and Thr. Compared with a complete EAA profile, supplementing only Ile, Leu, and Val reduced GE intake, resulted in a negative energy balance, was inhibitory to efficient milk protein synthesis, and increased the proportion of $\mathrm{N}$ intake excreted in urine. Flexibility in whole-body utilization of individual EAA, particularly the group 2 AA, should be taken into account when supplement- 
ing AA into dairy cattle diets. Consideration of this flexibility in ration formulation may allow optimization of $\mathrm{N}$ utilization through repartitioning of AA between catabolism and anabolism.

\section{ACKNOWLEDGMENTS}

The authors gratefully acknowledge technical assistance from Sven Alferink, Marcel Heetkamp, Tamme Zandstra, and the animal caretakers of the experimental facilities of "Carus" (Wageningen University and Research, Wageningen, the Netherlands), from Abby-Ann Redman and Marlies Schuldink (students of Wageningen University, Wageningen, the Netherlands), and from John Doelman (Trouw Nutrition R\&D, Boxmeer, the Netherlands). This research was conducted by Wageningen University and Research (Wageningen Livestock Research, Wageningen, the Netherlands), commissioned and funded by the Ministry of Agriculture, Nature and Food Quality (The Hague, the Netherlands) within the framework of Policy Support Research theme 'Feed4Foodure' (BO-31.03-005-001; TKI-AF12039B), and by the Vereniging Diervoederonderzoek Nederland (Rijswijk, the Netherlands).

\section{REFERENCES}

Arriola Apelo, S. I., J. R. Knapp, and M. D. Hanigan. 2014. Invited review: Current representation and future trends of predicting amino acid utilization in the lactating dairy cow. J. Dairy Sci. 97:4000-4017.

Bach, A., G. B. Huntington, S. Calsamiglia, and M. D. Stern. 2000. Nitrogen metabolism of early lactation cows fed diets with two different levels of protein and different amino acid profiles. J. Dairy Sci. 83:2585-2595.

Bequette, B. J., F. R. C. Backwell, J. C. MacRae, G. E. Lobley, L. A. Crompton, J. A. Metcalf, and J. D. Sutton. 1996. Effect of intravenous amino acid infusion on leucine oxidation across the mammary gland of the lactating goat. J. Dairy Sci. 79:2217-2224.

Bequette, B. J., C. E. Kyle, L. A. Crompton, V. Buchan, and M. D. Hanigan. 2001. Insulin regulates milk production and mammary gland and hind-leg amino acid fluxes and blood flow in lactating goats. J. Dairy Sci. 84:241-255.

Blouin, J. P., J. F. Bernier, C. K. Reynolds, G. E. Lobley, P. Dubreuil, and H. Lapierre. 2002. Effect of supply of metabolizable protein on splanchnic fluxes of nutrients and hormones in lactating dairy cattle. J. Dairy Sci. 85:2618-2630.

Brockman, R. P., and B. Laarveld. 1986. Hormonal regulation of metabolism in ruminants. A review. Livest. Prod. Sci. 14:313-334.

Brosnan, J. T., and M. E. Brosnan. 2006. Branched-chain amino acids: Enzyme and substrate regulation. J. Nutr. 136:207S-211S.

Calsamiglia, S., A. Ferret, C. K. Reynolds, N. B. Kristensen, and A. M. van Vuuren. 2010. Strategies for optimizing nitrogen use by ruminants. Animal 4:1184-1196.

Cant, J. P., D. R. Trout, F. Qiao, and B. W. McBride. 2001. Milk composition responses to unilateral infusion of complete and histidinelacking amino acid mixtures to the mammary glands of cows. J. Dairy Sci. 84:1192-1200.

Castillo, A. R., E. Kebreab, D. E. Beever, J. H. Barbi, J. D. Sutton, H. C. Kirby, and J. France. 2001. The effect of protein supplementation on nitrogen utilization in lactating dairy cows fed grass silage diets. J. Anim. Sci. 79:247-253.
Clark, J. H., H. R. Spires, R. G. Derrig, and M. R. Bennink. 1977. Milk production, nitrogen utilization and glucose synthesis in lactating cows infused postruminally with sodium caseinate and glucose. J. Nutr. 107:631-644.

Crown, S. B., N. Marze, and M. R. Antoniewicz. 2015. Catabolism of branched chain amino acids contributes significantly to synthesis of add-chain and even-chain fatty acids in 3T3-L1 adipocytes. PLoS One 10:e0145850.

CVB (Centraal Veevoederbureau). 2008. CVB Table Ruminants 2008, series nr. 43. CVB, The Hague, the Netherlands.

Dijkstra, J., O. Oenema, J. W. van Groenigen, J. W. Spek, A. M. van Vuuren, and A. Bannink. 2013. Diet effects on urine composition of cattle and $\mathrm{N}_{2} \mathrm{O}$ emissions. Animal 7(Suppl. 2):292-302.

Doelman, J., R. V. Curtis, M. Carson, J. J. M. Kim, J. A. Metcalf, and J. P. Cant. 2015a. Essential amino acid infusions stimulate mammary expression of eukaryotic initiation factor $2 \mathrm{~B} \varepsilon$ but milk protein yield is not increased during an imbalance. J. Dairy Sci. 98:4499-4508.

Doelman, J., J. J. M. Kim, M. Carson, J. A. Metcalf, and J. P. Cant. 2015b. Branched-chain amino acid and lysine deficiencies exert different effects on mammary translational regulation. J. Dairy Sci. 98:7846-7855.

Doepel, L., and H. Lapierre. 2010. Changes in production and mammary metabolism of dairy cows in response to essential and nonessential amino acid infusions. J. Dairy Sci. 93:3264-3274.

Doepel, L., D. Pacheco, J. J. Kennelly, M. D. Hanigan, I. F. López, and H. Lapierre. 2004. Milk protein synthesis as a function of amino acid supply. J. Dairy Sci. 87:1279-1297.

El-Kadi, S. W., R. L. Baldwin VI, N. E. Sunny, S. L. Owens, and B. J. Bequette. 2006. Intestinal protein supply alters amino acid, but not glucose, metabolism by the sheep gastrointestinal tract. J. Nutr. 136:1261-1269.

Fraser, D. L., E. R. Ørskov, F. G. Whitelaw, and M. F. Franklin. 1991. Limiting amino acids in dairy cows given casein as the sole source of protein. Livest. Prod. Sci. 28:235-252.

Gerrits, W. J. J., J. J. G. C. van den Borne, and E. Labussière. 2015. Deriving heat production from gaseous exchange: validity of the approach. Pages 19-34 in Indirect Calorimetry. Techniques, Computations and Applications. W. J. J. Gerrits and E. Labussière, ed. Wageningen Academic Publishers, Wageningen, the Netherlands.

Gietzen, D. W. 1993. Neural mechanisms in the responses to amino acid deficiency. J. Nutr. 123:610-625.

Gietzen, D. W., S. Hao, and T. G. Anthony. 2007. Mechanisms of food intake repression in indispensable amino acid deficiency. Annu. Rev. Nutr. 27:63-78.

Haque, M. N., H. Rulquin, A. Andrade, P. Faverdin, J. L. Peyraud, and S. Lemosquet. 2012. Milk protein synthesis in response to the provision of an "ideal" amino acid profile at 2 levels of metabolizable protein supply in dairy cows. J. Dairy Sci. 95:5876-5887.

Harper, A. E., N. J. Benevenga, and R. M. Wohlhueter. 1970. Effects of ingestion of disproportionate amounts of amino acids. Physiol. Rev. 50:428-558.

Heetkamp, M. J. W., S. J. J. Alferink, T. Zandstra, P. Hendriks, H. van den Brand, and W. J. J. Gerrits. 2015. Design of climate respiration chambers, adjustable to the metabolic mass of subjects. Pages 35-56 in Indirect Calorimetry. Techniques, Computations and Applications. W. J. J. Gerrits and E. Labussière, ed. Wageningen Academic Publishers, Wageningen, the Netherlands.

Huhtanen, P., and A. N. Hristov. 2010. Effects of energy and protein supply on milk protein yield responses in dairy cows. Pages 287-298 in Energy and Protein Metabolism and Nutrition. G. M. Crovetto, ed. EAAP publication No 127. Wageningen Academic Publishers, Wageningen, the Netherlands.

ISO. 1998. Animal feeding stuffs, animal products, and feces or urine. Determination of gross calorific value - Bomb calorimeter method. International Standards Organization, Geneva, Switzerland.

ISO. 2013. Milk and liquid milk products. Guidelines for the application of mid-infrared spectrometry. International Standards Organization, Geneva, Switzerland.

Kim, C., J. Choung, and D. G. Chamberlain. 2000. Variability in the ranking of the three most-limiting amino acids for milk protein 
production in dairy cows consuming grass silage and a cereal-based supplement containing feather meal. J. Sci. Food Agric. 80:13861392.

Lapierre, H., R. Berthiaume, G. Raggio, M. C. Thivierge, L. Doepel, D. Pacheco, P. Dubreuil, and G. E. Lobley. 2005. The route of absorbed nitrogen into milk protein. Anim. Sci. 80:11-22.

Lapierre, H., J. P. Blouin, J. F. Bernier, C. K. Reynolds, P. Dubreuil, and G. E. Lobley. 2002. Effect of supply of metabolizable protein on whole body and splanchnic leucine metabolism in lactating dairy cows. J. Dairy Sci. 85:2631-2641.

Lapierre, H., L. Doepel, E. Milne, and G. E. Lobley. 2009. Responses in mammary and splanchnic metabolism to altered lysine supply in dairy cows. Animal 3:360-371.

Lapierre, H., G. E. Lobley, L. Doepel, G. Raggio, H. Rulquin, and S. Lemosquet. 2012. Mammary metabolism of amino acids in dairy cows. J. Anim. Sci. 90:1708-1721.

Lobley, G. E. 1998. Nutritional and hormonal control of muscle and peripheral tissue metabolism in farm species. Livest. Prod. Sci. 56:91-114.

Lobley, G. E., and H. Lapierre. 2003. Post-absorptive metabolism of amino acids. Pages 737-756 in Progress in research on energy and protein metabolism. W. B. Souffrant and C. C. Metges, ed. Wageningen Academic Publishers, Wageningen, the Netherlands.

Maas, J. A., J. France, J. Dijkstra, A. Bannink, and B. W. McBride. 1998. Application of a mechanistic model to study competitive inhibition of amino acid uptake by the lactating bovine mammary gland. J. Dairy Sci. 81:1724-1734.

MacRae, J. C., L. A. Bruce, D. S. Brown, D. A. H. Farningham, and M. Franklin. 1997. Absorption of amino acids from the intestine and their net flux across the mesenteric- and portal-drained viscera of lambs. J. Anim. Sci. 75:3307-3314.

Martin, A. K., and K. L. Blaxter. 1965. The energy cost of urea synthesis in sheep. Pages 83-91 in Proceedings of the 3rd Symposium on Energy Metabolism. K. L. Blaxter, ed. Academic Press, London, UK.

Maxin, G., D. R. Ouellet, and H. Lapierre. 2013. Effect of substitution of soybean meal by canola meal or distillers grains in dairy rations on amino acid and glucose availability. J. Dairy Sci. 96:7806-7817.

Mepham, T. B. 1982. Amino acid utilization by lactating mammary gland. J. Dairy Sci. 65:287-298.

Metcalf, J. A., L. A. Crompton, D. Wray-Cahen, M. A. Lomax, J. D. Sutton, D. E. Beever, J. C. MacRae, B. J. Bequette, F. R. C. Backwell, and G. E. Lobley. 1996. Responses in milk constituents to intravascular administration of two mixtures of amino acids to dairy cows. J. Dairy Sci. 79:1425-1429.

Nichols, K., A. Bannink, S. Pacheco, H. J. van Valenberg, J. Dijkstra, and H. van Laar. 2018. Feed and nitrogen efficiency are affected differently but milk lactose production is stimulated equally when isoenergetic protein and fat is supplemented in lactating dairy cow diets. J. Dairy Sci. 101:7857-7870.
Nichols, K., J. Dijkstra, H. van Laar, S. Pacheco, H. J. van Valenberg, and A. Bannink. 2019. Energy and nitrogen partitioning in dairy cows at low or high metabolizable protein levels is affected differently by postrumen glucogenic and lipogenic substrates. J. Dairy Sci. 102:395-412.

Nichols, K., J. J. M. Kim, M. Carson, J. A. Metcalf, J. P. Cant, and J. Doelman. 2016. Glucose supplementation stimulates peripheral branched-chain amino acid catabolism in lactating dairy cows during essential amino acid infusions. J. Dairy Sci. 99:1145-1160.

NRC. 2001. Nutrient Requirements of Dairy Cattle. 7th rev. ed. Natl. Acad. Sci., Washington, DC.

Raggio, G., D. Pacheco, R. Berthiaume, G. E. Lobley, D. Pellerin, G. Allard, P. Dubreuil, and H. Lapierre. 2004. Effect of level of metabolizable protein on splanchnic flux of amino acids in lactating dairy cows. J. Dairy Sci. 87:3461-3472.

Reed, K. F., H. C. Bonfá, J. Dijkstra, D. P. Casper, and E. Kebreab. 2017. Estimating the energetic cost of feeding excess dietary nitrogen to dairy cows. J. Dairy Sci. 100:7116-7126.

Schwab, C. G., L. D. Satter, and A. B. Clay. 1976. Response of lactating dairy cows to abomasal infusion of amino acids. J. Dairy Sci 59:1254-1270

Spek, J. W., J. Dijkstra, G. van Duinkerken, and A. Bannink. 2013 A review of factors influencing milk urea concentration and its relationship with urinary urea excretion in lactating dairy cattle. J. Agric. Sci. 151:407-423.

Tagari, H., K. Webb Jr., B. Theurer, T. Huber, D. DeYoung, P. Cuneo, J. E. P. Santos, J. Simas, M. Sadik, A. Alio, O. Lozano, A. Delgado-Elorduy, L. Nussio, C. M. M. Bittar, and F. Santos. 2008. Mammary uptake, portal-drained visceral flux, and hepatic metabolism of free and peptide-bound amino acids in cows fed steamflaked or dry-rolled sorghum grain diets. J. Dairy Sci. 91:679-697.

Van Es, A. J. H. 1978. Feed evaluation for ruminants. I. The systems in use from May 1977-onwards in The Netherlands. Livest. Prod. Sci. 5:331-345.

van Gastelen, S., E. C. Antunes-Fernandes, K. A. Hettinga, G. Klop, S. J. J. Alferink, W. H. Hendriks, and J. Dijkstra. 2015. Enteric methane production, rumen volatile fatty acid concentrations, and milk fatty acid composition in lactating Holstein-Friesian cows fed grass silage- or corn silage-based diets. J. Dairy Sci. 98:1915-1927.

Vernon, R. G., E. Finley, and E. Taylor. 1985. Fatty acid synthesis from amino acids in sheep adipose tissue. Comp. Biochem. Physiol. B 82:133-136.

Weekes, T. L., P. H. Luimes, and J. P. Cant. 2006. Responses to amino acid imbalances and deficiencies in lactating dairy cows. J. Dairy Sci. 89:2177-2187.

Wright, T. C., S. Moscardini, P. H. Luimes, P. Susmel, and B. W. McBride. 1998. Effects of rumen-undegradable protein and feed intake on nitrogen balance and milk production in dairy cows. J. Dairy Sci. 81:784-793. 